\title{
UJI BAKTERI Escherichia coli PADA AIR SUNGAI PIAM DI KECAMATAN SIRAPIT KABUPATEN LANGKAT
}

\author{
Ari Anggara ${ }^{1}, K_{a r t i k a}$ Manalu $^{2}$, dan Rasyidah ${ }^{3}$ \\ Biologi, Fakultas Sains dan Teknologi, Universitas Islam Negeri Sumatera Utara \\ Anggararii06@gmail.com
}

\begin{abstract}
ABSTRAK
This study aims to determine the presence of Escherichia coli bacterial contamination in Piam River Water. The method used in this study is using the purpose sampling observation method with three station points and three repeats. The results are readed in the MPN table. The results showed that the presence of Escherichia coli bacterial contamination in Piam River water with the lowest MPN yield was $38 \mathrm{CFU}$ and the highest was $1100 \mathrm{CFU}$. The average MPN value on Eschericbia coli bacterial contamination at station 1 in the morning was $59 \mathrm{CFU}$ and afternoon was $111 \mathrm{CFU}$. Station 2 in the morning $128 \mathrm{CFU}$ and afternoon $303 \mathrm{CFU}$. And at station 3 in the morning $92 \mathrm{CFU}$ and afternoon 886 CFU.
\end{abstract}

Keywords: Escherichia coli bacteria, MPN method, Piam River water.

\section{PENDAHULUAN}

Sungai Piam merupakan sungai yang berada di Kecamatan Sirapit Kabupaten Langkat. Sungai Piam melintasi tiga kelurahan yang terdapat di Kecamatan Sirapit yaitu Kelurahan Serapit, Kelurahan Sidorejo dan berhulu di Kecamatan Pulau Semikat dengan panjang sungai 4,06 km dan luas $\pm 50 \mathrm{~m}$.

Air Sungai Piam berwarna hijau kekuningan dan keruh diakibatkan adanya buangan limbah domestik yang mengalir di Sungai Piam. Disisi lain, air Sungai Piam masih dimanfaatkan oleh masyarakat sekitar untuk mandi, cuci, kakus (MCK) dan memancing. Bagian dari limbah domestik yang paling berbahaya ialah mikroorganisme patogen yaitu bakteri Escherichia coli yang terdapat dalam tinja (Arisman, 2009).

Escherichia coli merupakan bakteri yang umum ditemukan di perairan. Escherichia coli menjadi indikator air yang terkontaminasi tinja dari manusia ataupun hewan. Bakteri ini dapat menyebabkan terjadinya penyakit pada manusia. Pemantauan dan kebijakan dalam pengolaan kualitas air serta pengendalian pencemaran air dapat meminimalisir pencemaran limbah domestik untuk mempertahankan kualitas air
Sungai Piam yang dimanfaatkan oleh masyarakat (Purnaini dkk, 2017).

Penelitian sebelumnya menunjukkan jumlah koloni bakteri Escherichia coli yang diidentifikasi pada air Sungai Pagesangan Kota Mataram sebanyak 54 CFU dan termasuk dalam kategori kurang baik mengacu pada Permenkes Nomor 416 Tahun 1990 (Hujja, 2018). Selain itu, kelimpahan koloni bakteri Coliform dan Colifecal pada air Sungai Natumandi di kawasan pemukiman penduduk Kecamatan Tarutung diperoleh hasil MPN paling rendah $34 \mathrm{CFU}$ dan paling tinggi 1000 CFU. Hal ini berarti air sungai Natumandi tidak berada pada kisaran yang diperbolehkan untuk mandi, cuci, kakus (MCK) mengacu pada Permenkes Nomor 32 Tahun 2017 (Simbolon, 2018). Penelitian ini dilakukan dengan tujuan untuk mengetahui ada tidaknya cemaran bakteri Escherichia coli dan mengetahui tingkat kelayakan air Sungai Piam di Kecamatan Sirapit Kabupaten Langkat.

\section{METODE PENELITIAN}

Populasi penelitian ini adalah bakteri Escherichia coli di Perairan Sungai Piam di Kecamatan Sirapit Kabupaten Langkat. Sampel penelitian diperoleh 
dengan menggunakan metode purposive sampling dan teknik pengumpulan data menggunakan teknik observasi.

Pengambilan sampel dilakukan pada 3 titik stasiun pemantauan. Stasiun 1 : bagian hulu Sungai Piam yang merupakan titik awal aktivitas. Stasiun 2 : bagian pusat kawasan yang aktif oleh aktivitas masyarakat seperti mandi, mencuci, kakus, membuang sampah dan limbah domestik. Stasiun 3 : bagian hilir yang merupakan aktivitas akhir dari Sungai Piam. Pengambilan sampel dilakukan pada masing-masing titik stasiun pada pagi hari (08.00 WIB) dan sore hari (17.00 WIB) menggunakan 3 kali ulangan.

Penelitian ini menggunakan peralatan yaitu autoklaf, inkubator, tabung reaksi, rak tabung reaksi, tabung durham, pipet serologi $10 \mathrm{ml}$, pipet serologi 1,0 $\mathrm{ml}$, bunsen, korek, ose bengkok, botol steril, termos es, cawan petri, kapas, aluminium foil dan kertas label. Bahan yang digunakan pada uji ini adalah sampel air Sungai Piam, media pertumbuhan bakteri seperti media LB (Lactose Broth), media BGLB (Briliant Green Lactose Broth) dan EMBA (Eosin Metil Blue Agar).

Selanjutnya sampel diuji di laboratorium menggunakan uji pendugaan (presumptive test), uji penegasan (confirmed test) dan uji pelengkap (complete test). Uji pendugaan (presumptive test)

Uji pendugaan dilakukan untuk melihat kehadiran Coliform. Terbentuknya asam dapat dilihat dari kekeruhan pada media LB (Lactose Broth) dan terbentuknya gas pada tabung durham menunjukkan adanya fermentasi laktosa dan menyatakan pertumbuhan positif dan dilanjutkan dengan uji penegasan.

Uji penegasan (Confirmed Test)

Pengujian ini dilakukan pada hasil yang dinyatakan positif saat uji pendugaan. Sampel ini diinokulasikan secara aseptik dengan ose ke dalam tabung yang berisi media BGLB (Brilliant Green Lactose
Broth) selanjutnya diinkubasi dengan suhu $44^{\circ} \mathrm{C}$ selama 1x24 jam. Apabila terbentuknya gas dalam tabung durham maka dinyatakan positif. Jumlah bakteri Escherichia coli dihitung dengan menggunakan Tabel MPN (Tabel 1) (Sunarti, 2015).

Tabel 1 Nilai MPN 3 Seri Tabung

\begin{tabular}{|c|c|c|c|c|c|c|c|c|c|c|c|}
\hline \multicolumn{12}{|c|}{$\begin{array}{c}\text { Tabel MPN untuk } 3 \text { seri tabung dengan } 0,1,0,01 \text { dan } 0,001 \mathrm{~g} \text { inokulum } \\
(95 \% \text { confidence intervas } s)^{2}\end{array}$} \\
\hline \multicolumn{3}{|c|}{ Tabung positif } & \multirow{2}{*}{ MPN/g } & \multicolumn{2}{|c|}{ Conf. lim. } & \multicolumn{3}{|c|}{ Tabung positif } & \multirow{2}{*}{$\mathrm{MPN} / \mathrm{g}$} & \multicolumn{2}{|c|}{ Conf. 1 im. } \\
\hline 0.10 & 0.01 & 0.001 & & bwah & atas & 0.10 & 0.01 & 0.001 & & bwah & atas \\
\hline 0 & 0 & 0 & $<3.0$ & - & 9.5 & 2 & 2 & 0 & 21 & 4.5 & 42 \\
\hline o & 0 & 1 & 3.0 & 0.15 & 9.6 & 2 & 2 & 1 & 28 & 8.7 & 94 \\
\hline o & 1 & o & 3.0 & 0.15 & 11 & 2 & 2 & 2 & 35 & 8.7 & 94 \\
\hline o & 1 & 1 & 6.1 & 1.2 & 18 & 2 & 3 & o & 29 & 8.7 & 94 \\
\hline o & 2 & 0 & 6.2 & 1.2 & 18 & 2 & 3 & 1 & 36 & 8.7 & 94 \\
\hline o & 3 & o & 9.4 & 3.6 & 38 & 3 & o & 0 & 23 & 4.6 & 94 \\
\hline 1 & o & o & 3.6 & 0.17 & 18 & 3 & 0 & 1 & 38 & 8.7 & 110 \\
\hline 1 & $\mathrm{o}$ & 1 & 7.2 & 1.3 & 18 & 3 & 0 & 2 & 64 & 17 & 180 \\
\hline 1 & o & 2 & 11 & 3.6 & 38 & 3 & 1 & 0 & 43 & 9 & 180 \\
\hline 1 & 1 & 0 & 7.4 & 1.3 & 20 & 3 & 1 & 1 & 75 & 17 & 200 \\
\hline 1 & 1 & 1 & 11 & 3.6 & 38 & 3 & 1 & 2 & 120 & 37 & 420 \\
\hline 1 & 2 & o & 11 & 3.6 & 42 & 3 & 1 & 3 & 160 & 40 & 420 \\
\hline 1 & 2 & 1 & 15 & 4.5 & 42 & 3 & 2 & 0 & 93 & 18 & 420 \\
\hline 1 & 3 & 0 & 16 & 4.5 & 42 & 3 & 2 & 1 & 150 & 37 & 420 \\
\hline 2 & o & o & 9.2 & 1.4 & 38 & 3 & 2 & 2 & 210 & 40 & 430 \\
\hline 2 & o & 1 & 14 & 3.6 & 42 & 3 & 2 & 3 & 290 & 90 & 1,000 \\
\hline 2 & o & 2 & 20 & 4.5 & 42 & 3 & 3 & 0 & 240 & 42 & 1,000 \\
\hline 2 & 1 & o & 15 & 3.7 & 42 & 3 & 3 & 1 & 460 & 90 & 2,000 \\
\hline 2 & 1 & 1 & 20 & 4.5 & 42 & 3 & 3 & 2 & 1100 & 180 & 4,100 \\
\hline 2 & 1 & 2 & 27 & 8.7 & 94 & 3 & 3 & 3 & $>1100$ & 420 & - \\
\hline
\end{tabular}

Uji pelengkap (Complete Test)

Pada uji pelengkap, tabung yang dinyatakan positif pada tes penegasan diinoklasikan dengan ose ke dalam media EMBA dan diinkubasi pada suhu $37{ }^{\circ} \mathrm{C}$. Jika koloni tumbuh dengan ciri berwarna hijau metalik pada masa inkubasi 1-2 hari maka dapat diinterprestasikan bahwa koloni tersebut merupakan Escherichia coli (Khotimah, 2013).

Teknik analisis data menggunakan teknik perhitungan kelimpahan bakteri (MPN). Kualitas air Sungai Piam dideskripsikan berdasarkan Peraturan Menteri Kesehatan Nomor 32 tahun 2017 tentang Standar Baku Mutu Kesehatan Lingkungan. Persyaratan kesehatan air didasarkan pada Surat Keputusan Menteri KLH No. 02/MenKLH/1/1988 tentang Penggolongan Air dan Peraturan Pemerintah Nomor 82 tahun 2001 tentang Pengelolan Kualitas Air dan Pengendalian Pencemaran Air. 


\section{HASIL DAN PEMBAHASAN}

Uji Pendugaan (presumptive test)

Sampel yang telah diuji menunjukkan hasil positif dengan terbentuknya gelembung gas pada tabung durham dan media berubah menjadi keruh. Hasil positif dilanjutkan dengan uji penegasan.

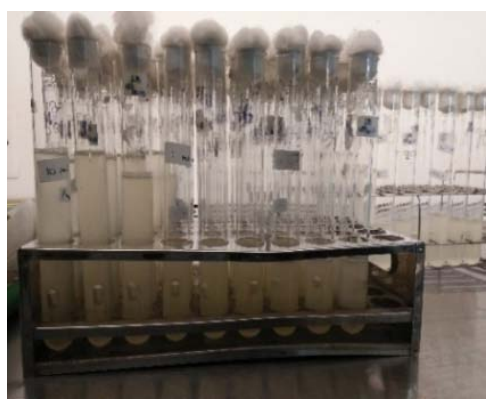

Gambar 1 Hasil positif terbentuknya gelembung gas

Uji penegasan (Confirmed Test)

Sampel yang diuji menunjukkan hasil positif dengan terbentuknya gelembung gas pada tabung durham dan media berubah menjadi keruh. Hasil uji penegasan dapat dilihat pada Gambar 2.

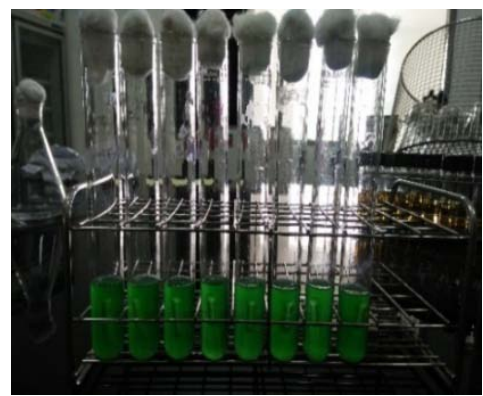

Gambar 2 Hasil positif terbentuknya gelembung gas Selain itu, dapat pula diamati hasil uji penegasan dari Tabel 2 berikut ini.

Tabel 2. Rata-rata jumlah koloni Escherichia coli di air Sungai Piam Kec. Sirapit Kabupaten Langkat

\begin{tabular}{|c|c|c|c|c|c|c|c|}
\hline \multirow{2}{*}{$\begin{array}{l}\mathbf{N} \\
\mathbf{o}\end{array}$} & \multirow{2}{*}{ Parameter } & \multirow{2}{*}{$\begin{array}{c}\text { Titik } \\
\text { Stasiun }\end{array}$} & \multirow{2}{*}{ Waktu } & \multicolumn{3}{|c|}{ Ulangan (CFU) } & \multirow{2}{*}{$\begin{array}{c}\text { Rata- } \\
\text { rata } \\
\text { (CFU) }\end{array}$} \\
\hline & & & & 1 & 2 & 3 & \\
\hline \multirow{2}{*}{1} & Total Colifecal & \multirow{2}{*}{ Stasiun 1} & Pagi & 38 & 75 & 64 & 59 \\
\hline & E. coli & & Sore & 120 & 120 & 93 & 111 \\
\hline \multirow{2}{*}{2} & Total Colifecal & \multirow{2}{*}{ Stasiun 2} & Pagi & 75 & 150 & 160 & 128 \\
\hline & E. coli & & Sore & 160 & 290 & 460 & 303 \\
\hline \multirow{2}{*}{3} & Total Colifecal & \multirow{2}{*}{ Stasiun 3} & Pagi & 64 & 120 & 93 & 92 \\
\hline & E. coli & & Sore & 460 & 1100 & 1100 & 886 \\
\hline 4 & Escherichia coli & & & + & + & + & \\
\hline
\end{tabular}

Uji pelengkap (Complete Test)

Hasil uji penegasan diperoleh hasil positif tumbuhnya koloni berwarna hijau metalik dengan bentuk bulat (secara langsung) yang disebut dengan bakteri Escherichia coli.

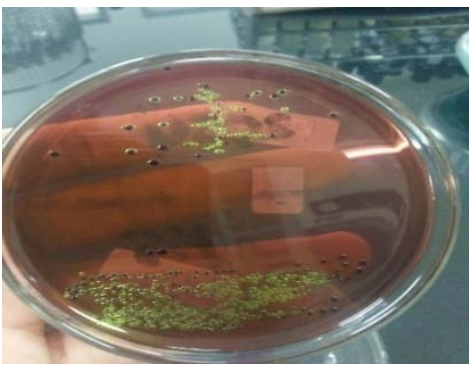

Gambar 3. Hasil positif bakteri Escherichia coli pada media EMBA

Rata-rata jumlah koloni Escherichia coli di air Sungai Piam Kecamatan Sirapit Kabupaten Langkatpada tabel 2menunjukkan jumlah total bakteri Escherichia coli yang beragam. Mengacu pada Surat Keputusan Menteri KLH No. 02/MenKLH/1/1988 tentang penggolongan air dan baku mutu yang digunakan pada kriteria mutu air sesuai Peraturan Menteri Kesehatan Nomor 32 Tahun 2017 tentang Standar Baku Mutu Kesehatan Lingkungan dan persyaratan kesehatan air untuk keperluan hygiene sanitasi, kolam renang, solus per aqua (SPA), dan pemandian umum menyatakan bahwa batas maksimum total bakteri Escherichia coli adalah 126 CFU.

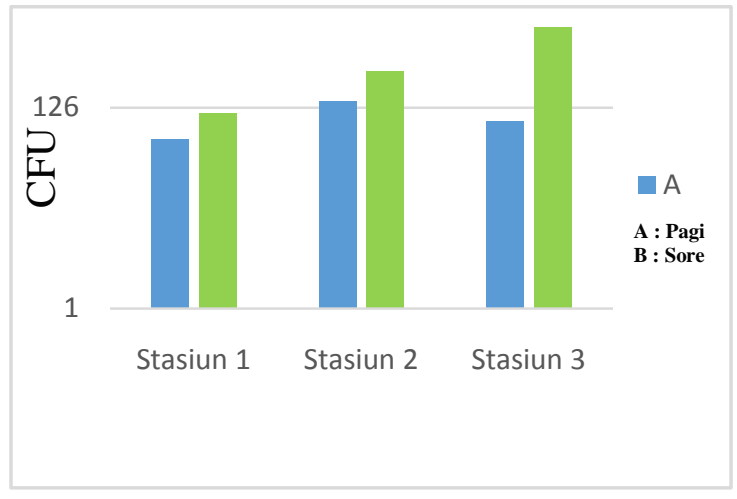

Gambar 4 Grafik total bakteri Escherichia coli

Pada stasiun 1 diperoleh hasil < 126 CFU, hal tersebut terjadi karena stasiun 1 merupakan hulu Sungai 
Piam dengan sedikitnya aktivitas dan pasokan limbah. Pada stasiun 2 dan 3 diperoleh hasil $>126$ CFU, hal ini dikarenakan stasiun 2 merupakan titik yang aktif digunakan masyarakat sekitar seperti mandi, mencuci, kakus, dan pembuangan sisa limbah domestic. Sedangkan stasiun 3 merupakan titik akhir aktivitas dari Sungai Piam.

Hasil uji bakteri Escherichia coli pada stasiun 1, 2 dan 3 dapat menjadi bahan pertimbangan terhadap Peraturan Menteri Kesehatan Nomor 32 Tahun 2017 tentang Standar Baku Mutu Kesehatan Lingkungan dan Persyaratan Kesehatan Air dan Surat Keputusan Menteri KLH No. 02/MenKLH/1/1988 tentang penggolongan air. Berdasarkan peraturan tersebut, air Sungai Piam termasuk dalam kriteria Mutu Air Kelas II dan digolongkan ke dalam golongan B. Mutu Air Kelas II yaitu air yang peruntukkannya dapat digunakan untuk prasarana/sarana rekreasi air, pembudidayaan ikan air tawar, peternakan, air untuk mengairi pertanaman, dan atau peruntukkan lain yang mempersyaratkan mutu air yang sama dengan kegunaan tersebut. Sedangkan kriteria air golongan B yaitu air baku untuk minum dan kebutuhan rumah tangga.

Jumlah bakteri Escherichia coli pada sore hari relative $>126$ CFU. Hal ini dikarenakan terjadinya fase $\log$ (pertumbuhan bakteri yang sangat cepat) pada fase ini terjadi proses pertumbuhan bakteri yang cepat, karena kecukupan daya dukungnya. Salah satu daya dukung bakteri ialah komposisi media yaitu nutrisi pada media berupa sumber energi dan kondisi lingkungannya. Semakin banyak nutrisi pada media, maka akan semakin meningkatkan pertumbuhan dari bakteri tersebut. Faktor ini membuat sel membelah dengan kecepatan cepat (Indotesis, 2017). Hal tersebut sesuai dengan hasil penelitian pada air Sungai Piam, adanya sumber nutrisi dari aktivitas masyarakat dari pagi sampai sore hari seperti mandi, cuci, kakus dan kondisi lingkungan disekitaran sungai sebagai tempat buangan limbah domestik yang mempengaruhi proses tumbuh bakteri secara cepat.

Sedangkan pada pagi hari jumlah bakteri Escherichia coli < 126 CFU karena terjadinya fase stasioner dan fase kematian. Salah satu faktor daya dukung fase stasioner ialah komposisi media, berkurangnya kadar nutrisi akan menggangu proses pembelahan sel, dan berkurangnya jumlah bakteri. Fase ini berlanjut pada fase kematian dengan ditandai peningkatan jumlah kematian yang lebih dibanding laju pertumbuhan (Indotesis, 2017). Hal ini sebanding dengan kondisi pada air Sungai Piam. Aktivitas masyarakat berakhir pada sore hingga menjelang pagi, menyebabkan berkurangnya sumber nutrisi bagi bakteri untuk hidup.

\section{KESIMPULAN}

Hasil pemeriksaan uji bakteri Escherichia coli pada Air Sungai Piam di Kecamatan Sirapit Kabupaten Langkat menunjukkan adanya cemaran bakteri Escherichia coli pada air sungai tersebut dengan hasil MPN paling rendah 38 dan paling tinggi 1100 CFU.

Tingkat kelayakan air Sungai Piam di Kecamatan Sirapit Kabupaten Langkat ditinjau dari parameter bakteri Escherichia coli ialah terdapat 2 stasiun yang tercemar oleh bakteri Escherichia coli dengan angka rata-rata $303 \mathrm{CFU}$ dan $886 \mathrm{CFU}$. Hasil tersebut > 126 CFU mengacu pada Permenkes Nomor 32 Tahun 2017.

\section{SARAN}

Perlu dilakukan penelitian lanjutan untuk mengetahui jenis bakteri lain yang mempengaruhi cemaran di Sungai Piam Kecamatan Sirapit Kabupaten Langkat. 


\section{DAFTAR PUSTAKA}

Arisman. 2009. Keracunan Makanan. Buku Kedokteran EGC. Jakarta.

Hujja, F. 2018. Isolasi Identifikasi Bakteri Escherichia coli pada Sungai Pagesangan Kota Mataram Tahun 2017. Skripsi. Fakultas Tarbiyah dan Keguruan, Universitas Islam Negeri Mataram. Mataram.

Indotesis. 2017. Pertumbuhan Bakteri, bttps://medium.com/@indotesis/pertumbubanbakte ri-bb470217d257. (Diakses pada tanggal 10 Desember 2019 pukul 14:05 WIB).

Khotimah, S. 2013. Kepadatan Bakteri Coliform di Sungai Kapuas Kota Pontianak. Prosiding Semirata. FMIPA Universitas Lampung. Lampung.

Purnaini, R., Sudarmadji, dan Suryo, P. 2017. Kualitas Air Sungai Kapuas Kecil Bagian Hilir pada Kondisi Pasang dan Surut. Seminar Nasional Penerapan Ilmu Pengetahuan Dan Teknologi 2017. Pontianak.

Simbolon, S.V. 2018. Analisis Kualitas Air Sungai Natumandi Berdasarkan Kelimpahan Coliform, Colifecal di Kecamatan Tarutung Kabupaten Tapanuli Utara. Skripsi. FMIPA Universitas Negeri Medan. Medan.

Sunarti. R.N. 2015. Uji Kualitas Air Sumur dengan Menggunakan Metode MPN (Most Probable Number). Jurnal Biolmi 1(1): 32-33. 